\title{
Pendekatan Diagnostik Refluks Laring Faring
}

\author{
Karin I. Rompas, ${ }^{1}$ Steward K. Mengko, ${ }^{2}$ Ora Et Labora I. Palandeng ${ }^{2}$
}

\author{
${ }^{1}$ Program Studi Pendidikan Dokter Fakultas Kedokteran Universitas Sam Ratulangi, Manado, \\ Indonesia \\ ${ }^{2}$ Bagian Ilmu THT-KL Fakultas Kedokteran Universitas Sam Ratulangi, Manado, Indonesia \\ Email: karinrompas09@gmail.com
}

\begin{abstract}
Lifestyle and behavior changes can have bad impacts on our health. One of the diseases that can be caused by lifestyle changes is pharyngeal larynx reflux. Pharyngeal laryngeal reflux is a state of return of the contents of the stomach to the larynx and pharynx causing an inflammatory reaction to the mucous membranes of the larynx and pharynx. In an attempt to diagnose pharyngeal larynx reflux, a follow-up examination is required. In this case there are several examinations that can be done to confirm the diagnosis of pharyngeal larynx reflux. This study was aimed to obtain the diagnostic approaches in laringopharyngeal reflux cases. This was a literature review study using two databases namely PubMed and ClinicalKey. The keywords used were laringophaingeal reflux and laryngopharyngeal reflux disease. After being selected based on inclusion and exclusion criteria, nine literatures using experimental research methods. were obtained. The results showed that several examinations that could be performed in diagnosing laringofaringeal reflux, as follows: anamnesis, physical examination, $\mathrm{pH}$-monitoring, reflux findings score, reflux symptom score, PEP-test, reflux sign assessment, reflux symptom score, immunohistochemistry, and fiber-optic laryngoscopy. In conclusion, supporting examinations are needed to confirm the diagnosis of pharyngeal larynx reflux.
\end{abstract}

Keywords: refluks laring faring; laryngopharyngeal reflux disease.

\begin{abstract}
Abstrak: Perubahan gaya hidup dan perilaku dapat berdampak pada kesehatan tubuh. Salah satu penyakit yang dapat diakibatkan oleh perubahan gaya hidup yaitu refluks laring faring. Refluks laring faring merupakan keadaan kembalinya isi lambung ke laring dan faring sehingga menyebabkan reaksi inflamasi pada selaput lendir laring dan faring. Untuk menegakkan diagnosis refluks laring faring dibutuhkan pemeriksaan lanjutan. Penelitian ini bertujuan untuk mengetahui pendekatan diagnosis yang dapat dilakukan dalam pemeriksaan kasus refluks laring faring. Jenis penelitian ialah literature review dengan pencarian data menggunakan dua database yaitu PubMed dan ClinicalKey. Kata kunci yang digunakan yaitu refluks laring faring and laryngopharyngeal reflux disease. Setelah diseleksi berdasarkan kriteria inklusi dan eksklusi, didapatkan sembilan literatur yang menggunakan metode penelitian eksperimental. Hasil penelitian mendapatkan pemeriksaan-pemeriksaan yang dilakukan dalam menegakkan diagnosis refluks laring faring ialah: anamnesis, pemeriksaan fisik, $\mathrm{pH}$-monitoring, skor temuan refluks, skor gejala refluks, PEP-test, reflux sign assessment, reflux symptom score, immunohistochemistry, dan fiberoptic laryngoscopy. Simpulan penelitian ini ialah pemeriksaan penunjang perlu dilakukan untuk menegakkan diagnosis refluks laring faring.
\end{abstract}

Kata kunci: refluks laring faring; laryngopharyngeal reflux disease

\section{PENDAHULUAN}

Seiring perkembangan zaman dan proses modernisasi terjadi berbagai perubahan perilaku, sikap dan gaya hidup

seseorang. Perubahan gaya hidup dan perilaku tersebut dapat berdampak buruk pada kesehatan tubuh yang dapat menjadi rentan 
untuk terkena penyakit. Salah satu penyakit yang dapat diakibatkan oleh perubahan gaya hidup yaitu refluks laring faring (RLF). ${ }^{1}$

Refluks laring faring merupakan salah satu penyakit yang terjadi di sekitar laring dan faring yang dapat dicetuskan akibat perilaku gaya hidup yang modern dan kebiasaan diet yang buruk. Berdasarkan data survei di beberapa negara di Asia yang sampelnya diambil dari dokter spesialis THT di Asia Barat dan Asia Timur ditemukan sebanyak $70 \%$ pasien yang didiagnosis sebagai RLF. ${ }^{2}$ Selain itu di negara Barat juga dilaporkan diagnosis terkait RLF berkisar $10-30 \%,{ }^{3}$ sedangkan di Indonesia pada tahun 2018 terdapat $20-30 \%$ pasien dengan keluhan laring terdiagnosis dengan RLF. Beberapa tanda dari RLF yang sering ditemukan yaitu edema plika vokalis (79\%), hiperemia (79\%) dan edema laring difus (76\%). Terkait RLF. $50-78 \%$ pada orang tua disertai dengan gangguan suara mencapai 91\%. ${ }^{4}$ Diagnosis RLF dapat dicapai melalui berbagai metode pemeriksaan. Beberapa peneliti mengaitkan RLF dengan manifesttasi lanjut penyakit refluks gastro esofagus (PRGE). ${ }^{1}$

Langkah awal untuk diagnosis RLF ialah melalui anamnesis yang teliti terkait riwayat penyakit keluarga, kebiasaan diet, pola hidup, dan predisposisi genetik. ${ }^{1}$ Kasus RLF dapat didiagnosis dengan berbagai cara di antaranya tes PPI, multichannel intraluminal impedance monitoring (MII-PH), esophageal bilirubin monitoring, mechanical sensory barotest, pemantauan $\mathrm{pH} 24$ jam, endoskopi saluran cerna bagian atas, exhaled breath condensate (EBC), dan pemeriksaan RLF dengan kuesioner terstandarisasi. ${ }^{1}$

Pemeriksaan $\mathrm{pH}$-monitoring dapat mendeteksi secara langsung paparan asam pada esofagus dan laring; oleh karena itu pemeriksaan ini dapat dianggap sebagai pemeriksaan terbaik dalam mengumpulkan bukti untuk diagnosis sehingga disebut sebagai pemeriksaan baku emas dari PRGE. ${ }^{5}$ Beberapa penelitian telah menunjukkan hasil terapi RLF yang didiagnosis melalui pemantauan $\mathrm{pH}$-monitoring.

Selain pemeriksaan $\mathrm{pH}$-monitoring dapat juga dilakukan pemeriksaan skor gejala refluks (SGR) dan skor temuan refluks (STR). ${ }^{6}$ Skor temuan refluks (STR) merupakan pemeriksaan yang secara kuantitatif mengevaluasi dan menilai keadaan laring dengan menggunakan alat nasofaringolaringoskop fleksibel. Selain itu ditemukan tanda-tanda lain yaitu edema subglotis, obliterasi ventrikularis, eritema, edema plika vokalis, edema laring difus, hipertrofi komisura posterior, jaringan granulasi/granuloma, sekret kental di laring dengan sensitifitas $87,8 \%$ dan spesifitas $37,5 \%{ }^{4}$ Apabila nilai temuan melebihi 7 maka diagnosis RLF dapat ditegakkan. ${ }^{6}$

Skor gejala refluks (SGR) merupakan kuesioner yang menilai keluhan terbanyak yang ditemukan pada pasien RLF yang dirangkum dalam gejala-gejala. Sampai saat ini belum ada standar baku emas yang pasti untuk pemeriksaan untuk diagnosis RLF sehingga berbagai metode dapat digunakan maupun dikombinasikan dengan penilaian berbagai gejala pada kuesioner SGR ataupun penilaian kuantitatif pemeriksaan nasofaringolaringoskop pada STR. ${ }^{7}$ Berdasarkan hal tersebut diatas, maka penulis tertarik untuk melakukan suatu literatur review terkait berbagai metode pendekatan untuk diagnosis RLF.

\section{METODE PENELITIAN}

Penelitian ini merupakan suatu literatur review. Pencarian data menggunakan dua database dengan kriteria yang ditentukan yaitu Pubmed dan ClinicalKey. Kata kunci yang digunakan dalam pencari artikel yaitu refluks laring faring and laryngopharyngeal reflux disease. Artikel yang direview ialah artikel jurnal penelitian berbahasa Indonesia atau Inggris.

\section{HASIL PENELITIAN}

Berdasarkan pencarian literatur melalui database elektronik Pubmed dan Clinical key dengan kata kunci yang digunakan dalam pencarian literatur adalah refluks laring faring and laryngopharyngeal reflux disease didapatkan sebanyak 1,956 literatur. Dari hasil pencarian yang didapatkan kemudian dilakukan skrining, dan diperoleh 
956 literatur. Dari 956 literatur tersebut sesuai dengan kata kunci dilakukan skrining. Terdapat 175 literatur dieksklusi karena tidak tersedia fulltext. Kemudian 781 literatur fulltext dilakukan asesmen kelayakan, dan didapatkan 436 literatur fulltext yang kemudian dieksklusi karena tahun publikasi tidak sesuai kriteria inklusi, sehingga dida- patkan sembilan literatur fulltext yang dilakukan review.

Setelah melalui tahap seleksi studi didapatkan Sembilan literatur yang memenuhi kriteria inklusi. Tabel 1 memperlihatkan distribusi penulis/populasi/ pemeriksaan, cara pemeriksaan, dan hasil penelitian.

Tabel 1. Distribusi penulis, populasi, pemeriksaan, dan hasil penelitian

\begin{tabular}{|c|c|c|}
\hline $\begin{array}{c}\text { Penulis } \\
\text { (Negara/Tahun)/ } \\
\text { Populasi/ } \\
\text { Pemeriksaan }\end{array}$ & Cara pemeriksaan & Hasil \\
\hline $\begin{array}{l}\text { Aulia } \mathrm{W}^{8} \\
(\text { Indonesia/2020)/ } \\
1 \text { orang pasien pria/ } \\
\text { Anamnesis }\end{array}$ & $\begin{array}{l}\text { Yang perlu ditanyakan: } \\
\text { - Menanyakan keluhan pasien? } \\
\text { - Apakah pasien mengalami perubahan suara } \\
\text { serak? } \\
\text { - Jika pasien mengalami perubahan suara serak, } \\
\text { tanyakan sudah sejak kapan? } \\
\text { - Apakah pasien sempat mengalami hilangnya } \\
\text { suara? } \\
\text { - Jika pasien sempat mengalami hilangnya suara, } \\
\text { tanyakan apakah sebelum pasien mengalami } \\
\text { keluhan tersebut pasien sempat mengalami } \\
\text { demam? } \\
\text { - Apakah pasien mengalami batuk kering? } \\
\text { - Apakah pasien mengalami kesulitan menelan? } \\
\text { - Bagaimana kebiasaan pola makan pasien akhir- } \\
\text { akhir ini? } \\
\text { - Apakah pasien memiliki kebiasaan telat } \\
\text { makan? } \\
\text { - Apakah pasien pernah atau sedang menjalani } \\
\text { pengobatan tertentu? } \\
\text { - Tanyakan juga riwayat penyakit pasien? }\end{array}$ & $\begin{array}{l}\text { Pada pasien RLF pada anamnesis } \\
\text { ditemukan: } \\
\text { - Suara serak. } \\
\text { - Nyeri menelan. } \\
\text { - Suara hilang timbul. } \\
\text { - Mengalami demam. } \\
\text { - Batuk kering. } \\
\text { - Kesulitan menelan. } \\
\text { - Pasien biasanya sering } \\
\text { memiliki kebiasaan telat } \\
\text { makan. } \\
\text { - Biasanya ada riwayat penyakit } \\
\text { dispepsia. }\end{array}$ \\
\hline $\begin{array}{l}\text { Aulia } \mathrm{W}^{8} \\
\text { (Indonesia/2020)/ } \\
1 \text { orang pasien pria/ } \\
\text { Pemeriksaan Fisik }\end{array}$ & $\begin{array}{l}\text { Pemeriksaan menggunakan laringoskopi indirek } \\
\text { dilakukan dengan cara: } \\
\text { - Pasien dalam posisi duduk diminta untuk } \\
\text { membuka dan menjulurkan lidah. Tutup lidah } \\
\text { dengan kain kasa kemudian tarik mengguna- } \\
\text { kan jari jempol dan jari tengah. } \\
\text { - Kemudian masukkan dan arahkan cermin } \\
\text { kearah belakang tenggorokkan, kemudian arah- } \\
\text { kan cermin kearah uvula dan palatum mole. } \\
\text { - Putar cermin sampai menghadap keseluruh } \\
\text { sudut untuk mendapatkan visualisasi yang } \\
\text { maksimal. }\end{array}$ & $\begin{array}{l}\text { Pada pemeriksaan ini biasanya } \\
\text { ditemukan: } \\
\text { - Mukosa laring hiperemis. } \\
\text { - Edema eritenoid } \\
\text { - Adanya sekret. } \\
\text { - Epiglotis, valekula dan plika } \\
\text { vokalis terlihat edema. }\end{array}$ \\
\hline $\begin{array}{l}{\text { Plocek et } \text { al }^{9}} \\
\text { (Polandia/2019)/ } \\
23 \text { pasien anak/ } \\
\text { PH - Monitoring } \\
24 \text { jam }\end{array}$ & $\begin{array}{l}\text { - Kateter dengan diameter } 2,3 \mathrm{~mm} / 6,9 \mathrm{Fr} \text { dengan } \\
6 \text { saluran impedansi dan } 1 \text { sensor } \mathrm{pH} \text { diposisi- } \\
\text { kan ditengah saluran impedansi paling distal } \\
\text { kedua. } \\
\text { - Kateter dikalibrasi dalam penyangga dengan } \\
\text { pH } 4 \text { dan } 7 \text { dan dimasukkan melalui nares } \\
\text { anterior, tanda bahwa penempatan kateter su- } \\
\text { dah benar akan dikonfirmasi oleh radiografi. } \\
\text { - Kemudian diposisikan } 3 \mathrm{~cm} \text { diatas tepi } \\
\text { proksimal bagian bawah sfingter esophagus. }\end{array}$ & $\begin{array}{l}\text { Episode refluks asam didefinisi- } \\
\text { kan sebagai penurunan tingkat } \mathrm{pH} \\
\text { mulai dari nilai awal }>4,0 \text { hingga } \\
\text { nilai }<4,0 \text { setelah adanya refluks } \\
\text { fisik. Jika nilai } \mathrm{pH} \text { berkisar } 4-7 \\
\text { diklasifikasikan sebagai refluks } \\
\text { asam lemah, sedangkan bila } \mathrm{pH} \\
\geq 7,0 \text { diklasifikasikan sebagai basa } \\
\text { lemah. } \\
\text { Episode refluks khusus pH didefi- }\end{array}$ \\
\hline
\end{tabular}


Wu et $\mathrm{al}^{7}$

(China/2019)/

225 pasien pria dan wanita dewasa /

Skor Temuan Refluks

(STR)

Yu et al ${ }^{10}$
(China/2019)/ (63 pasien pria dan wanita
dewasa/
Skor Gejala Refluks
(SGR)

Iannella et $\mathrm{al}^{11}$

(Itali/2019)/

75 pasien pria dan wanita dewasa/

PEP-Test
- 6 sinyal impedansi dan $\mathrm{pH}$ akan terekam pada $50 \mathrm{~Hz}$ setiap 0,02 detik.

- Setelah memposisikan kateter PH di dalam kerongkongan sebuah probe $\mathrm{PH}$ dimasukkan melalui nares yang samadan diposisikan di dinding posterior faring ditingkat uvula.

- PH diukur secara langsung setiap 0,5 detik menggunakan sensor yang berada diujung probe PH.

- Kemudian data yang dikumpulkan oleh probe PH ditransmisikan oleh gelombang radio.

- Rekaman ini dilakukan selama 24 jam, selama itu pasien diinstruksikan untuk melakukan kegiatan sehari-hari seperti biasanya.

- Selama 24 jam juga, pasien atau keluarga pasien diminta untuk mendata mengenai tandatanda yang dialami pasien, makanan yang dikonsumsi dan posisi tubuh pasien.

Setelah 24 jam kateter akan dikeluarkan dan data yang diperoleh akan diunduh dari logger ke komputer untuk pengembangan hasil tes.

Pemeriksaan STR dilakukan berdasarkan temuan laringoskopi. STR memuat skala keparahan klinis yang terdiri dari 8 item yang digunakan untuk menafsirkan temuan laringoskopi umum yang terkait RLF.

SGR merupakan pemeriksaan kuesioner penilaian mandiri yang terdiri dari 9 pertanyaan terkait gejala mengenai tingkat keparahan batuk, faktorfaktor yang memperingan atau memperburuk gejala, bersamaan dengan post-nasal drip, regurgittioni dan mulas. Sistem skor terdiri dari 6 poin yaitu dari 0-5 dengan total skor 45 .

- Sampel saliva diambil pada dini hari sekitar jam 07.00-08.00 pada pasien dalam posisi tegak menggunakan mikropipet dengan tabung silikon berdiameter $0,3 \mathrm{~cm}$ dengan panjang $2 \mathrm{~cm}$ dan potongan miring pada $45^{\circ}$

- Silikon yang mengarah ke tangki kecil dengan diameter $0,5 \mathrm{~cm}$ dan panjang $2 \mathrm{~cm}$ yang disediakan dengan tabung hisap, setelahnya sampel langsung diambil dari rongga mulut.

- Sampel dianalisis menggunakan PEP-test segera setelah pengumpulan sampel untuk menghindari kerusakan spesimen.

- Setiap sampel disentrifugasi pada $400 \mathrm{rpm}$ selama 5 menit pada suhu kamar normal.

- Kemudian $80 \mu \mathrm{L}$ supernatant dikumpulkan dan ditambahkan ke $240 \mu \mathrm{L}$ migration buffer kemudian dicampur untuk 10 s: $80 \mu \mathrm{L}$ campuran ini dikloning ke sumur Perangkat Aliran Lateral Pep-test. Setelah 15 menit hasilnya akan keluar.

Lechien et al ${ }^{12}$

(Belgia/2020)/

106 pasien pria dan wanita dewasa/

Reflux Sign Assessment (RSA) yang dibagi tiga bagian yaitu rongga mulut, faring dan laring. Jika ditemukan granuloma lipat vokal, keratosis atau ulserasi, maka masing-masing ditambahkan 2 skor yang dapat menjadi pertimbangan dalam item terakhir skor, yang jika nisikan sebagai jatuhnya $\mathrm{PH}$ distal ke $<4,0$ yang berlangsung setidaknya 5 detik terdeteksi oleh sensor $\mathrm{pH}$.

Perangkat lunak dari pemeriksaan $\mathrm{pH}$ akan menghitung persentase ketika tingkat $\mathrm{pH}$ dalam faring turun sehingga parameter ini akan memungkinkan pemeriksaan lainnya yang merujuk ke indeks insiden RLF.

Pasien dengan temuan STR $>7$ dianggap patologik dan didiagnosis dengan RLF.

Jika total skor dari pemeriksaan SGR > 13 maka semakin tinggi probabilitas RLF.

Jika hasil dari PEP-test positif maka pasien dianggap positif RLF.

Jika RSA > 14 maka dianggap positif kemungkinan RLF. 
Lechien et al ${ }^{13}$

(Belgia/2019)/

20 pasien pria dan wanita dewasa/

Reflux Symptom Score (RSS)

Gong et $\mathrm{a}^{14}$

(China/2017) /

26 pasien pria dan wanita dewasa /

Immunohistochemistry

(IHC)

Lemyze et a ${ }^{15}$

(Prancis/2017) /

17 pasien pria dan wanita dewasa/

Fiber-optic Laringoskopi (FOL) dijumlahkan total skornya adalah 72 .

- RSS ini dalam bentuk kuesioner yang dibagi menjadi lima bagian yang terdiri dari telinga, hidung, tenggorok, pencernaan dan pernapasan. Frekuensi dan tingkat keparahan setiap gejala dinilai masing-masing 5 poin skala, setiap titik pengukuran frekuensi secara tepat didefinisikan.

- Untuk setiap item, skor tingkat keparahan dikalikan dengan frekuensi untuk mendapatkan skor gejala berkisar antara 0 hingga 25 . Kemudian, jumlah skor gejala ini dihitung untuk mendapatkan final skor RSS

- Pada akhir kuesioner, pasien diundang untuk menentukan apakah kuesioner telah menilai semua keluhan yang ditemui (ya/tidak).

- Spesimen yang dikumpulkan ditanam dalam parafin dan dibahagi menjadi $4 \mu \mathrm{m}$ bagian.

- Bagian yang disematkan parafin kemudian diwarnai dalam xylene dan rehydrated dengan melewati seri $100 \%, 95 \%, 75 \%$, dan $50 \%$ etanol yang diikuti dengan air.

- Aktivitas peroxidase endogen dihambat dengan mengerami jaringan dalam 0,3\% $\mathrm{H} 2 \mathrm{O} 2$ selama 10 menit pada suhu kamar.

- Setelah memblocking dengan 5\% goat serum normal diencerkan dalam buffere fosfat saline, bagian-bagian diinkubasi dengan pengenceran 1:75 primary rabbit anti-human pepsin antibody pada suhu kamar selama 2 jam.

- Setelah dicuci, peroxidase menghubungkan kedua antibody baru kemudian diizinkan untuk mengikat pada suhu kamar selama 1 jam.

- Untuk semua bagian, pewarnaan pepsin divisualisasikan dengan 3, 3'- diaminobenzidine diikuti dengan counterstaining dengan meyer hematoxylin, dihidrasi dan kemudian disusun.

Di bawah anestesi topikal dengan lidokain 4\%, serat optic flexibel nasopharynglaryngoscopy dimasukkan melalui nasal untuk mengevaluasi area faring posterior, tulang rawan arytenoid, plika vokalis, dan hubungan dengan tabung endotrakeal dan tabung nasogastrik. Contoh yang dinilai misalnya jika ditemukan: edema (terlokalisasi atau difus); ulserasi (dangkal ditutupi dengan mukosa atau dalam); granulasi.

Pada saat anterior tipis berbentuk V membuka plika vokalis bisa divisualisasikan hanya dengan meneruskan ke tabung endotrakeal dengan pasien segera diekstubasi.
Skor RSS > 13 dapat dianggap sugestif gejala terkait RLF.

Kepadatan warna coklat dan angka dari sel yang positif dievaluasi atau dihitung dalam 5 bidang daya.

Kepadatan warna coklat dicetak sebagai berikut:

Pewarnaan negatif $=0$; coklat lemah $=1$; coklat $=2$; dan coklat gelap $=3$ (Kepositifan sel dicetak sebagai berikut:

$-<25 \%$ kepositifan $=1$

$-25 \% \sim 50 \%$ kepositifan $=2$;

- 51\% 75\% kepositifan $=3$;

- dan $>75 \%$ kepositifan $=4$.

Sedangkan, dengan mengatur skor warna kepadatan dan kepositifan seluler, pewarnaan dicetak sebagai berikut: $0=$ negatif; $1-4=$ positif lemah; 5-8 = positif; $9-12=$ sangat positif.

Hasil pengamatan dari pemeriksaan FOL ini kemudian dapat ukur menggunakan pemeriksaan STR untuk kemudian dapat diperiksa lebih lanjut.

\section{BAHASAN}

Dalam bahasan ini akan diulas mengenai anamnesis, pemeriksaan fisik, $\mathrm{pH}$ monitoring, skor temuan refluks (STR), skor gejala refluks (SGR), PEP-test, reflux sign assessment (RSA), reflux symptom score (RSS), immunohistochemistry (IHC), dan fiber-optic laryngoscopy (FOL).
Pada awal anamnesis ditanyakan identitas dan keluhan pasien, jika pasien datang dengan mengeluhkan tanda-tanda khas dari RLF dan hasil dari awal sampai akhir anamnesis menimbulkan kecurigaan mengarah ke RLF maka pemeriksaan dapat dilanjutkan dengan pemeriksaan fisik menggunakan laringoskopi indirek. ${ }^{8}$ 
Pemeriksaan fisik diawali dengan memeriksa tanda-tanda vital yang terdiri dari pemeriksaan tekanan darah, pernapasan, nadi, suhu, berat badan dan tinggi badan, kemudian, dilanjutkan melihat keadaan umum pasien. Selanjutnya dilakukan pemeriksaan dengan menggunakan alat laringoskopi indirek untuk mengetahui adanya mukosa laring hiperemis, edema eritenoid, adanya secret, dan plika vokalis terlihat edema. ${ }^{8}$

Untuk pemeriksaan $\mathrm{pH}$-monitoring, saat ini pemantauan $\mathrm{PH}$ kerongkongan ambulasi tersedia dalam dua bentuk: sistem pemantauan $\mathrm{pH}$ berbasis kateter dan sistem $\mathrm{pH}$ nirkabel. Sistem $\mathrm{pH}$ nirkabel merupakan teknologi pemantauan $\mathrm{pH}$ bebas kateter yang bekerja melalui kapsul diposisikan secara transoral yang melekat pada kerongkongan distal, dan mengirimkan pembacaan $\mathrm{pH}$ kerongkongan ke penerima eksternal melalui telemetri. Dibandingkan dengan sistem berbasis kateter konvensional, sistem pH nirkabel lebih baik ditoleransi oleh pasien, memungkinkan pemantauan selama periode yang lama (hingga 96 jam), dan meningkatkan akurasi hasil diagnostik paparan asam kerongkongan yang abnormal. ${ }^{16}$ Peristiwa refluks diidentifikasi sebagai asam ketika $\mathrm{pH}<4$ dan asam lemah ketika $\mathrm{pH}>4$ dengan penurunan cepat terkait dalam intraluminal impedansi berkembang secara proksimal. Peristiwa gas diidentifikasi ketika impedansi meningkat di semua saluran, dan peristiwa gas/cair ketika terdapat kombinasi dari keduanya. Sensitivitas dan spesifitas dari pemeriksaan $\mathrm{pH}$ monitoring ialah $96 \%$ dan $100 \% .{ }^{17}$

Indikasi pemeriksaan skor temuan refluks (STR) yaitu pada pasien dengan keluhan pada bagian tenggorok, seperti keluhan perubahan suara dan kliring tenggorok yang konstan. ${ }^{1}$ Temuan dari hasil kuesioner RFS ini kemudian dinilai sesuai skornya. Jika skor yang ditemukan lebih dari 7 diduga pasien positif RLF. Pemeriksaan ini memiliki sensitifitas $87,8 \%$ dan spesifitas $37,5 \% .^{18}$

Pemeriksaan skor gejala refluks (SGR) terdapat dalam bentuk kuesioner yang nantinya akan dilengkapi sendiri oleh pasien. Dasar pemeriksaan ini tidak berbeda dengan dasar pemeriksaan RLF yang lain, yaitu jika ditemukan pasien dengan keluhan di tenggorok seperti disfonia, throat clearing, sensasi globus, batuk kronis, postnasal drip, serta disfagia. Jika dalam pemeriksaan ini skor pasien lebih dari 15 maka dianggap pasien terindikasi RLF. Pemeriksaan ini memiliki sensitifitas $78,4 \%$ dan spesifitas $95,4 \% .^{19}$

Salivary specimen collection and salivary pepsin concentration estimation atau biasa disingkat dengan PEP-test merupakan pemeriksaan yang bertujuan untuk mendeteksi pepsin dalam saliva. Pemeriksaan ini didasarkan pada reaksi imunohistokimia (reaksi antibodi-antibodi) menggunakan antibodi anti-pepsin monoklonal (garis $\mathrm{T}$ mengungkapkan kehadiran pepsin). Selain itu, sistem ini melibatkan kontrol reaksi inti yang berguna untuk memperkirakan integritas sistem (garis C). Tes ini valid ketika mendapatkan reaksi yang terkait dengan kontrol internal (IC, garis C). Keberadaan garis T menunjukkan bahwa pepsin terdapat dalam sampel yang diuji dan selanjutnya intensitas garis $\mathrm{T}$ berbanding lurus dengan kuantitas pepsin. ${ }^{11}$ Pada pemeriksaan PEPtest juga dapat digunakan alat PEP-test cube. Alat ini adalah perangkat aliran lateral elektronik kecil yang menampilkan hasil pepsin analisis konsentrasi dalam cairan yang berbeda langsung dalam $\mathrm{ng} / \mathrm{mL}$ hanya dalam beberapa detik. ${ }^{11}$ Pemeriksaan PEPtest ini memiliki sensitifitas dan spesifitas $87 \% .^{20}$

Pemeriksaan reflux sign assessment (RSA) dikembangkan untuk diagnosis dan tindak lanjut pasien RLF yang dicurigai atau yang memiliki diagnosis oleh pemeriksaan pH. Pemeriksaan RSA terdiri dari tanda, sistem penilaian, dan presentasi. Dengan pemeriksaan ini, sistem penilaian yang mengklasifikasikan tanda-tanda sebagai "ringan," "sedang," atau "parah" dihindari demi sistem penilaian yang deskriptif sebisa mungkin. Jika nilai skor dari pemeriksaan ini melebihi 14 maka dianggap pasien terindikasi RLF. Pemeriksaan ini memiliki sensitifitas dan spesifitas $89,1 \%$ dan $95,2 \% .^{21}$ 
Pemeriksaan reflux symptom score (RSS) dikembangkan untuk diagnosis dan tindak lanjut pasien yang dicurigai RLF atau yang memiliki diagnosis oleh pemeriksaan pH. Pemeriksaan RSS terdiri dari tanda, sistem penilaian, dan presentasi dengan sensitifitas dan spesifitas $94,5 \%$ dan $81,0 \% .^{5,13}$

Pemeriksaan immunohistochemistry (IHC) dilakukan dengan cara pertama-tama biopsi bagian yang akan menjadi sampel untuk diperiksa (dalam hal ini yaitu leukoplakia plika vokalis). Hasil dari pemeriksaan ini yaitu jika ditemukan pepsin dari hasil biopsi maka pemeriksaan dinyatakan positif sehingga pemeriksaan imunohistokimia dapat menjadi biomarker RLF. ${ }^{14}$ Sensitifitas dari pemeriksaan ini yaitu $97,1 \%$ dengan spesifitas $74,4 \% .^{22}$. Dengan interpretasi kepositifan sel dicetak sebagai berikut: $<25 \%$ kepositifan $=1 ; 25 \%-50 \%$ kepositifan $=2 ; 51 \%-75 \%$ kepositifan $=3$; $>75 \%$ kepositifan $=4 .{ }^{17}$ Pemeriksaan fiber optic laryngoscopy (FOL) bertujuan untuk melihat dan menilai secara langsung gejalagejala yang ditemukan pada pasien dan hasilnya dapat didokumentasikan dalam pemeriksaan STR. Sensitifitas dan spesifitas pemeriksaan ini ialah $69,2 \%$ dan $98,4 \% .{ }^{15}$

\section{Pemberian terapi pada refluks laring faring}

Terapi pada refluks laring faring meliputi pemberian proton pump inhibitor (PPI), prokinetik, alginate, serta perubahan pola makan dan perilaku.

Proton pump inhibitor (PPI) mengurangi sekresi lambung $\mathrm{H}^{+}$melalui berikatan secara kovalen dengan $\mathrm{H}^{+} / \mathrm{K}^{+} \mathrm{ATP}$. PPI meningkatkan $\mathrm{pH}$ droplet gas refluks dan membatasi aktivitas ekstrasel pepsin pada jaringan saluran cerna atas. Namun, dari sudut pandang patofisiologi, PPI tidak berdampak pada aktivitas intrasel pepsin dan memiliki dampak rendah pada aktivitas garam empedu tripsin yang dapat melukai mukosa laringofaringeal. PPI memiliki short half-life yaitu 90 menit dengan dosis oral $20 \mathrm{mg}$ dan menghambat $70 \%$ pompa enzim. Penghambatan sekresi asam lambung berlangsung sekitar 24 jam. Sekitar
$20 \%$ pompa proton baru disintesis selama periode 24 jam dengan sintesis pompa yang lebih besar di malam hari daripada siang hari. Penambahan waktu tidur tidak akan menambah penghambatan terobosan asam, karena obat akan menghilang pada saat sekresi asam terjadi pada malam hari. Diasumsikan sekitar 70\% dari pompa aktif pada saat sarapan PPI diberikan 30-60 menit sebelumnya sehingga penghambatan keadaan stabil pada dosis sekali sehari ialah sekitar $66 \%$ dari hasil asam maksimal. Dengan kata lain, meningkatkan dosis hampir tidak berpengaruh setelah dosis optimal tercapai. Namun, meningkatkan frekuensi dosis memang memiliki beberapa efek; dosis pagi dan dosis malam sebelum makan menghasilkan sekitar $80 \%$ penghambatan hasil asam maksimal. ${ }^{23}$

Penambahan prokinetik terhadap PPI masih kontroversial. Beberapa studi melaporkan bukti tentang keunggulan kombinasi PPI dan prokinetik terhadap PPI saja. Demikian pula beberapa penelitian uji coba acak menyarankan bahwa penambahan prokinetik ke PPI akan dikaitkan dengan peningkatan gejala yang lebih baik. ${ }^{23}$

Alginate bekerja dnegan membentuk 'rakit' yang mengambang di atas isi lambung yang dapat dipertahankan di dalam perut hingga 4 jam. Sebuah studi membuktikan bahwa panjang rantai polimer dan kelompok yang dapat diionisasi berperan menyediakan biofilm pelindung pada mukosa kerongkongan dan saluran aerodigestif atas. Dalam sebuah penelitian ditunjukkan bahwa keunggulan alginate atas plasebo dalam pengobatan pasien RLF. Perawatan berdasarkan penggunaan alginate tunggal cukup kompetitif dengan perawatan yang menggabungkan PPI dan alginate. ${ }^{23}$

Perubahan pola makan dan perilaku tetap menjadi langkah terapeutik pertama pada perawatan pasien dengan RLF. Selain itu, pengobatan ini merupakan pengobatan empiris hemat biaya yang terbaik untuk pasien dengan RLF. Pasien yang taat melakukan diet dan perubahan perilaku memiliki gejala yang lebih baik daripada yang tidak melakukan diet. Penelitian terbaru menunjukkan bahwa diet yang dilakukan dengan 
baik dapat seefisien pengobatan PPI. Diet alkali, diet protein, diet rendah lemak, dan diet rendah asam sangat efektif karena jenis makanan ini dicerna dengan baik, dan juga dapat mengurangi relaksasi sfingter esogfagus. $^{23}$

\section{SIMPULAN}

Pendekatan diagnosis refluks laring faring dapat dilakukan melalui beberapa pemeriksaan, yaitu: anamnesis, pemeriksaan fisik, pH-monitoring, skor temuan refluks, skor gejala refluks, $P E P$-test, reflux sign assessment, reflux symptom score, imunohistokimia dan fiber-optic laryngoscopy. Pemeriksaan menggunakan skor gejala refluks (SGR) dianggap sebagai salah satu pemeriksaan yang mudah untuk dilakukan dan dinilai.

\section{Konflik Kepentingan}

Penulis menyatakan tidak terdapat konflik kepentingan dalam studi ini.

\section{DAFTAR PUSTAKA}

1. Kirti YK. Reflux finding score (RFS) a quantitative guide for diagnosis and treatment of laryngopharyngeal reflux. Indian J Otolaryngol Head Neck Surg [Internet]. 2018;70(3):362-5. Available from: https://doi.org/10.1007/s12070018-1350-3

2. Kim S Il, Lechien JR, Ayad T, Jia H, Khoddami SM, Enver N, et al. Management of laryngopharyngeal reflux in Asia. Clin Exp Otorhinolaryngol. 2020;13(3):299307.

3. Lechien JR, Chiesa-Estomba CM, Henriquez CC, Mouawad F, Ristagno C, Barillari MR, et al. Laryngopharyngeal reflux, gastroesophageal reflux and dental disorders: a systematic review. PLoS One [Internet]. 2020;15(8 August). Available from: http://dx.doi.org/ 10.1371/journal.pone.0237581

4. Lechien JR, Huet K, Khalife M, Fourneau AF, Delvaux V, Piccaluga M, et al. Impact of laryngopharyngeal reflux on subjective and objective voice assessments: a prospective study. J Otolaryngol Head Neck Surg [Internet]. 2016;45(1): 1-9. Available from: http://dx.doi.org/ 10.1186/s40463-016-0171-1
5. Patel DA, Blanco M, Vaezi MF. Laryngeal disorder: perspective and common practice of the general gastroenterologist. Gastroentrol Hepatol (NY). 2018; 14(9):512-20.

6. Zhang C, Hu ZW, Yan C, Wu Q, Wu JM, Du $X$, et al. Nissen fundoplication vs proton pump inhibitors for laryngopharyngeal reflux based on $\mathrm{pH}$-monitoring and symptom-scale. World J Gastroenterol. 2017;23(19):3546-55.

7. Wu W, Li L, Qu C, Wang M, Liang S, Gao X, et al. Reflux finding score is associated with gastroesophageal flap valve status in patients with laryngopharyngeal reflux disease: a retrospective study. Sci Rep [Internet]. 2019;9(1):5-10. Available from: http://dx.doi.org/10.1038/ s41598-019-52349-5

8. Aulia W. Refluks laringofaring. Scripta Score Sci Med J. 2020;2(1):64-7.

9. Plocek A, Gębora-Kowalska B, Białek J, Fendler W, Toporowska-Kowalska E. Esophageal impedance-pH monitoring and pharyngeal $\mathrm{pH}$ monitoring in the diagnosis of extraesophageal reflux in children. Gastroenterol Res Pract. 2019;2019.

10. Yu Y, Wen S, Wang S, Shi C, Ding H, Qiu $\mathrm{Z}$, et al. Reflux characteristics in patients with gastroesophageal refluxrelated chronic cough complicated by laryngopharyngeal reflux. Ann Transl Med. 2019;7(20):529-529.

11. Iannella G, Vicini C, Polimeni A, Greco A, Gobbi R, Montevecchi $F$, et al. Laryngopharyngeal reflux diagnosis in obstructive sleep apnea patients using the pepsin salivary test. Int $\mathbf{J}$ Environ Res Public Health. 2019;16(11):1-10.

12. Lechien JR, Saussez S, Muls V, Barillari MR, Chiesa-Estomba CM, Hans S, et al. Laryngopharyngeal reflux: a stateof-the-art algorithm management for primary care physicians. J Clin Med. 2020;9(11):3618.

13. Lechien JR, Bobin F, Muls V, Thill MP, Horoi M, Ostermann K, et al. Validity and reliability of the reflux symptom score. Laryngoscope. 2020;130(3): E98-107.

14. Gong X, Wang XY, Yang L, Sun MJ, Du J, Zhang W. Detecting laryngopharyngeal reflux by immunohistochemistry of pepsin in the biopsies of 
vocal fold leukoplakia. J Voice [Internet]. 2018;32(3):352-5. Available from: http://dx.doi.org/10.1016/ j.jvoice.2017.06.010.

15. Lemyze M, Durville E, Meddour M, Jonard M, Temime J, Barailler S, et al. Impact of fiber-optic laryngoscopy on the weaning process from mechanical ventilation in high-risk patients for postextubation stridor. Med (United States). 2017;96(5):1-5.

16. Yadlapati R, Ciolino JD, Craft J, Roman S, Pandolfino JE. Trajectory assessment is useful when day-to-day esophageal acid exposure varies in prolonged wireless pH monitoring. Dis Esophagus. 2019; 32(3):1-7.1

17. Spyridoulias A, Lillie S, Vyas A, Fowler SJ. Detecting laryngopharyngeal reflux in patients with upper airways symptoms: Symptoms, signs or salivary pepsin? Respir Med [Internet]. 2015;109(8): 963-9. Available from: http://dx.doi.org/ 10.1016/j.rmed.2015.05.019

18. Powell J, Cocks HC. Mucosal changes in laryngopharyngeal reflux - Prevalence, sensitivity, specificity and assessment. Laryngoscope. 2013;123(4):985-91.

19. Eckley CA, Tangerina R. Sensitivity, specificity, and reproducibility of the Bra- zilian Portuguese version of the reflux symptom index. J Voice [Internet]. 2019. Available from: https://doi.org /10.1016/j.jvoice.2019.08.012

20. Saritas Yuksel E, Hong SKS, Strugala V, Slaughter JC, Goutte M, Garrett CG, et al. Rapid salivary pepsin test: Blinded assessment of test performance in gastroesophageal reflux disease. Laryngoscope. 2012;122(6): 1312-6.

21. Lechien JR, Rodriguez Ruiz A, Dequanter D, Bobin F, Mouawad F, Muls V, et al. Validity and Reliability of the Reflux Sign Assessment. Ann Otol Rhinol Laryngol. 2020;129(4):313-25..

22. Zafrani B, Aubriot MH, Mouret E, De Crémoux P, De Rycke Y, Nicolas A, et al. High sensitivity and specificity of immunohistochemistry for the detection of hormone receptors in breast carcinoma: comparison with biochemical determination in a prospective study of 793 cases. Histopathology. 2000;37(6):536-45.

23. Lechien JR, Mouawad F, Barillari MR, Nacci A, Khoddami SM, Enver N, et al. Treatment of laryngopharyngeal reflux disease: a systematic review. World J Clin Cases. 2019;7(19):2995-3011. 